\title{
SOUND SYSTEM CULTURE: PLACE, SPACE AND IDENTITY IN THE UNITED KINGDOM, 1960-1989
}

\author{
SOUND SYSTEM CULTURE: \\ LUGAR, ESPACIO E IDENTIDAD \\ EN EL REINO UNIDO, 1960-1989
}

\author{
Paul Ward \\ Edge Hill University, UK \\ ORCID: https://orcid.org/0000-0002-6044-9833
}

Recibido el 25-9-2017 y aceptado el 21-11-2017

\begin{abstract}
By exploring the experience of the industrial town of Huddersfield in West Yorkshire, where the West Indian population contributed to sound system and reggae culture out of proportion to its size, it can be shown that sound system culture developed differently in different urban contexts in Britain in the late twentieth century. The essay uses more than thirty oral history interviews of people who ran sound systems or were audiences for them. They were collected by the Sound System Culture project initiated by Let's Go Yorkshire, which focuses on aspects of local cultural heritage hidden from and unrecorded by mainstream history. Their project provides an opportunity to explore questions of identity in relation to sound systems, reggae and urban Britain with a focus on a specific place and its configurations of space. The essay examines the importance of the location of a West Indian club in the town centre, enabling the African-Caribbean population to visibly and aurally contribute to the Huddersfield's sense of its own identity.
\end{abstract}

Keywords: Reggae, sound systems, immigration, Black British history.

Resumen: A través del estudio de la experiencia de la ciudad industrial de Huddersfield, Yorkshire Oeste, donde la población antillana contribuyó a la cultura del sound system y el reggae en mayor proporción que su tamaño, se puede observar cómo la cultura sound system se desarrolló de modo diferente en di- 
versos contextos urbanos en la Gran Bretaña de finales del siglo xx. El artículo utiliza más de treinta entrevistas de historia oral a personas que dirigían sound systems o fueron su público. Estas fueron recopiladas por el proyecto Sound System Culture iniciado por el Let's Go Yorkshire, entidad que se interesa sobre aspectos del patrimonio cultural oculto o no documentado por la historia convencional. Su proyecto proporciona una oportunidad para explorar cuestiones relativas a la identidad relacionada con el sound system, reggae y el entorno urbano británico centrado en un lugar y configuración del espacio específico. El artículo examina la importancia del club West Indian situado en el centro de la ciudad, posibilitando que la población afro-caribeña contribuyera visible y sonoramente al sentido de Huddersfield de su propia identidad.

Palabras clave: Reggae, sound systems, inmigración, historia afroamericana británica. 
After 1948, the numbers of migrants to Britain from the West Indies increased substantially. Encouraged by poor economic conditions at home and a shortage of labour in Britain, tens of thousands of mainly young men arrived in the mother country seeking work. By the end of the twentieth century, there were half a million people of Caribbean birth or descent (as self-identified in the census of 1991) living in Britain, making them the second largest ethnic minority group in the country. The new arrivals experienced new ways of working and living, and above all the mixed but often hostile responses of much of the host population, who did not share the view of the British Nationality Act of 1948 that migrants from the British Empire were fellow British subjects entitled to settle in the United Kingdom. In such circumstances, facing racism and discrimination daily, they drew on their own histories and cultures and introduced them to the streets and neighbourhoods in which they now lived. This meant trying to recreate something familiar in the very different setting of urban Britain. For people from the West Indies, music played through sound systems, dancing, playing dominoes, drinking, chatting and socialising had been regular features of Caribbean life. Such activities could be recreated to remind people of where they came from and at the same time to make their new lives more tolerable and enjoyable and in the longer run could be used to assert their contribution to culture in their new places of residence in the United Kingdom.

This article uses oral history interviews to think about approaches to music and identity. It draws on interpretations from Paul Gilroy, Les Back and William 'Lez' Henry of the Caribbean experience and racism in Britain. Gilroy articulates how contemporary racism characterizes black people in Britain as being without history. He argues that 'anti-racism must respond by revealing and restoring the historical dimensions of black life in this country. ${ }^{1}$ This essay therefore explores reggae sound systems as a historically specific development in post-Second World War Britain, undertaken through the efforts of immigrants and their descendants from the West Indies. Back argued in the 1980s that, 'For many young black Britons living in London today, the reggae played by sound systems in dancehalls is inextricably related to coping with life in a white society. ${ }^{2}$ Henry elaborates that,

1 Gilroy, 1992, p. 18.

2 Back, 1988, p. 141. 
It was in the Reggae dancehall ... that black youth found a space to give vent to their concerns and engage in a cultural and political dialogue without the fear of reprisal or sanction from the state.... Reggae music, therefore, became a cultural template through which performers could consciously and intelligently express their innermost concern through the context of the British Sound System in the 1970s and 1980 s. $^{3}$

This essay examines, in particular, the way in which sound system culture was developed differently in different urban contexts in Britain, by exploring the experience of the industrial town of Huddersfield in West Yorkshire, where the West Indian population made a contribution to sound system and reggae culture out of proportion to its size. It does so by using more than thirty oral history interviews of people who ran sound systems or were audiences for them. As Gemma Romain argues, 'personal testimony must have a place within the analysis of ethnic minority migration history; the various oral testimony projects now accessible to historians need to be seriously utilised as a primary source of equal importance to traditional source material.' 4

The interviews used here were generated by a Heritage Lottery-funded project in the town undertaken between 2013 and 2016 called Sound System Culture..$^{5}$ It was an arts and heritage project that documented the lives and experiences of those who were involved in Huddersfield's reggae sound system culture. Led by Mandeep Samra and Let's Go Yorkshire, it was community designed and initiated with academic historians playing a supporting role. Let's Go Yorkshire focuses on aspects of local cultural heritage hidden from and unrecorded by mainstream history. ${ }^{6}$ The project involved several phases, including the collection of the oral histories; the development of a photographic exhibition; the production of a book and a film ${ }^{7}$; and the making of an interactive sound installation, built by Paul Huxtable of Axis Sound, which participated in African-Caribbean carnivals in northern England. All of the participants in the project were already involved in the sound system scene, with Huxtable being a leading

3 Henry, 2012, pp. 356, 359. Other books and essays on reggae include Bradley, 2001, Katz, 2003, and Hebdige, 2006, and Henriques, 2011.

${ }^{4}$ Romain, 2006, p. 16.

5 http://soundsystemcultureblog.tumblr.com/

${ }^{6}$ https://www.facebook.com/letsgoyorkshire/

7 Samra and Fingers, 2014; Sound System Culture: Huddersfield Trailer, 2014. 
deejay and soundman. The project was then developed further by Samra, gaining Arts Council England funding for exhibitions in Birmingham, Bristol and London. It has moved into a new phase in 2017, with a project called 'Let's Play Vinyl,' a touring exhibition that portrays UK sound system artists as productive entrepreneurs. As experiential research, enabling people to interact with the project's outputs, it uncovered the different cultural assumptions entailed in being black and British at the end of the twentieth century. While initiated by Samra, a heritage activist and oral historian of Sikh descent, volunteers and contributors from the Caribbean community participated in the project. Samra was interested in histories of different migrant groups to Britain and the project emerged from going to school in Deighton and hearing stories of blues parties, listening to reggae on pirate radio and her pleasure to learn that the main reggae venue in Huddersfield had been owned by the Sikh Bhullar brothers. However, much of the direction of the project emerged from the involvement of the African West Indian community, so for example, Amanda Huxtable, whose father migrated from Jamaica and ran a sound system in London conducted more than half the interviews, as well as being interviewed herself.

The project provides an opportunity to explore questions of identity in relation to sound systems, reggae and urban Britain with a focus on a specific place and its configurations of space. To do so, it examines patterns of Caribbean immigration in Britain and Huddersfield and outlines experiences of racism and the development of sound system culture to provide the background for understanding place and spatial specificity - or historical geography - of sound systems in Huddersfield as a way to comprehend that immigrants and their descendants were not a homogenous bloc of people but instead exerted their own agency in negotiating their lives in Britain in the streets, neighbourhoods and towns in which they lived. It argues that this resulted in an underpinning and contained culture that provided a basis for languages of resistance and community building across Black British society. Furthermore, it argues that, in Huddersfield, the configuration of the medium-sized town allowed encroachment into the town centre through the important West Indian venue of Venn Street. The history of the venue in turn has become an important part in understanding the town's musical heritage as a site of multiethnic encounters. 


\section{Immigration}

Despite a substantial pre-war and wartime history of Caribbean migration to Britain, the landing of the SS Empire Windrush at Tilbury on the River Thames in June 1948 has been mythologized as the onset of mass Black immigration into Britain. ${ }^{8}$ It is certainly the case that after this event, when close to 500 Jamaicans and Trinidadians (including two important calypso artists, Lord Kitchener and Lord Beginner) disembarked the ship, numbers of West Indians grew steadily in Britain. Between 1948 and 1962, when the first restrictive legislation on imperial/Commonwealth immigration was imposed, about 115,000 people from the Caribbean arrived in Britain ${ }^{9}$. West Indians were by no means the largest group of immigrants, being outnumbered by around 200,000 from South Asia, as well as 345,000 continental Europeans and hundreds of thousands of Irish-born people across Britain. ${ }^{10}$ From the start, there was a pathologisation of these new West Indian arrivals as 'dark strangers' different from the host population ${ }^{11}$. Hence Marcus Collins argues that 'the prominence of West Indian men was more than merely numerical. It was cultural, stemming from the fascination-cum revulsion of whites who customarily regarded them as vicious, indolent, violent, licentious, and antifamilial'. ${ }^{12}$ The main areas of West Indian settlement were London, the West Midlands, greater Manchester, the east Midlands, and West Yorkshire but even in these areas of concentration proportions were fairly low as late as 1991 (when the numbers were in decline). Hence, the proportion of those identifying as West Indians in greater London was 4.4 per cent of the population, in the West Midlands metropolitan area 2.8 per cent, in Manchester, 0.7 per cent, the east Midlands, 0.8 per cent (mainly in Nottingham) and in West Yorkshire, including Leeds and Huddersfield, West Indians constituted 0.7 per cent of the population. From the 1960s Yorkshire was experiencing a wave of non-white immigration as people were drawn from South Asia and the West Indies by employment in the textile mills, foundries, engineering and chemical works, as well as on public transport. In 1971 the population of the West Riding of Yorkshire stood at 3.8 mil-

\footnotetext{
8 Mead, 2009, 137-49 problematises the mythology of the Windrush.

9 Rush, 2007, p. 477.

${ }_{10}$ Rush, 2007, p. 477.

${ }_{11}$ See for example, Waters, 1997, pp. 207-38.

12 Collins, 2001, p. 391.
} 
lion, and it was estimated that there were only 85,000 non-white immigrants - that is 2.3 per cent of the population..$^{13}$ In Huddersfield in 1971, with a population of 131,000 , there were perhaps 5,000 West Indian people living in the town, mainly from Jamaica and Carriacou.

\section{Racism}

Responses to immigrants of colour were diverse. E.J.B. Rose's survey of British race relations in the late 1960s suggested that in areas with high proportions of Black and Asian immigration, over one-third of white interviewees expressed views with no trace of hostility and two-fifths were more 'strongly disposed in the direction of tolerance'. Sam Selvon's novel The Lonely Londoners (1956) illustrates the meaning of such 'toleration' of black people: 'Nobody in London does really accept you,' he wrote, 'They tolerate you, yes, but you can't go in their house and eat or sit down and talk' ${ }^{14}$. In Rose's survey, ten per cent of the host population - or around five million people - had 'almost unconditional antipathy' to black people and what would later be described as institutional racism was endemic in housing, employment, education, leisure and policing ${ }^{15}$. Panikos Panayi has convincingly argued that each new wave of immigrants to Britain experienced extreme hostility and racial violence including murder ${ }^{16}$ and West Indians met perhaps the most severe discrimination. There were anti-black racist riots in 1947 to 1949 in Birmingham and elsewhere ${ }^{17}$, in Notting Hill and Nottingham in $1958^{18}$, and in Middlesbrough in $1961^{19}$. In 1959 Kelso Cochrane was murdered by racists in London and killings have been a frequent reminder of the precariousness of life in multi-cultural Britain. In the 1970s police raids and attacks on African-Caribbean clubs and events were frequent, combining individual police officers' racism with the full force of institutional discrimination. ${ }^{20}$

13 Wade, 1972. The West Riding of Yorkshire was the administrative county that preceded the new county of West Yorkshire in 1974.

14 Gildart, 2013, p. 54.

15 Rose, 1969, p. 552-553.

16 Panayi, 1996.

17 Searle, 2013.

18 Pilkington, 1988.

19 Taylor, 1993.

20 See Bakari, 1989, p. 101-102. 
Gilroy identifies a shift in attitude among the police, when any encounter with West Indians came to be seen as holding potential for violence, and that in this context 'black parties and shebeens were gradually identified as sources of anti-police violence rather than simply places in which licensing laws were being broken'21. In the mid-1970s heavy policing of the Notting Hill Carnival resulted in riots in 1976, but it was day-today policing that played a major role in alienating young black people on Britain's streets. The 'Sus' laws, which gave the police powers under the 1824 Vagrancy Act to stop and search anyone they suspected of being a criminal, were a constant source of aggravation particularly in light of the media and legal construction of 'mugging' as a 'black crime' ${ }^{22}$. The Metropolitan Police's Special Patrol Group (SPG) became notorious for their racist policing. ${ }^{23}$ The police and violent racists went hand in hand in the eyes of many black people: 'In fear of attacks from fascists in the form of the National Front, or being picked up and beaten in the back of a police van, it was common practice not to go out alone, especially after dark' ${ }^{24}$.

Any discussion of racism in Britain in the late twentieth century must include the New Cross Massacre and the official response to it. On 18 January 1981, a fire was started at a sixteenth birthday party at $439 \mathrm{New}$ Cross Road in south east London and thirteen young black people were killed and another twenty-six were seriously injured. The police investigation was cursory, although they suspected that the house had been firebombed yet the coroner suggested that the fire was accidental. The black experience in Britain, therefore, included harassment, prejudice, violence and death with the state and media response being dismissive and discriminatory.

\section{Resistance}

Writing the history of Black, Asian and Minority Ethnic people in Britain has often focused on racism - the response of white people to immigrants and immigration - emphasizing the agency of the white British

${ }^{21}$ Gilroy, 1992, p. 128

${ }^{22}$ Hall, Critcher and Jefferson, 2013.

23 See https://www.youtube.com/watch?v=mnVnX-i5_hM for film from 1972 of the SPG stopping a black man driving his car in London.

${ }^{24}$ Riley, 2014, p. 105. 
rather than immigrants and minorities. Yet the response to the New Cross Fire displayed the agency of black people in Britain. On 2 March 1981, the New Cross Massacre Action Committee called a 'Black People's Day of Action' in which up to 20,000 people marched from New Cross to Hyde Park with placards reading ' 13 dead, nothing said.' In response to a police operation in Brixton called Swamp '81 later in the year, which involved massive number of stop and searches of black people, there was a wave of riots in Britain including major cities such as London, Liverpool, Birmingham, Manchester, but also smaller cities and towns including Bradford, Sheffield, Halifax, Hull and Huddersfield in Yorkshire ${ }^{25}$. Of course, these were not the first examples of resistance to racism in post-war Britain. A series of organisations and initiatives challenged discrimination and combatted racism more generally ${ }^{26}$. Among numerous examples, the bus boycott in Bristol against the employment colour bar provides an example of grassroots activism ${ }^{27}$. In the late 1960s, the British Black Power movement emerged and in the 1970s some black people converted to Rastafarianism, an Afrocentric religion. Such ideas drew on the sense of being part of an African-descended diaspora, drawing on movements in the United States and Africa ${ }^{28}$.

William Lez Henry argues that counter cultures provided a further adaptive response to racism and racial oppression in Britain ${ }^{29}$. Through music, an everyday cultural form, black people, many of whom were born in Britain, could express a sense of internal exile. Young people particularly used music and performance as a way of developing strategies of resistance to the oppressive and discriminatory state, employers, schools, and neighbours. Calypso (from Trinidad), mento, ska and rocksteady (from Jamaica) were imported from different islands in the West Indies, with the latter developing into reggae in the late 1960s. There were a series of bands who sang of the black experience - contributing to a black identity - including, for example, The Equals, who had a number one hit with 'Baby Come Back' in 1968, a pop tune, but who had released a track called 'Police on my back' in 1967 (later covered by the punk band

25 See Sivanandan, 1981, for the classic account of racism, resistance and rebellion in this period.

${ }^{26}$ See for example Ramdin, 1987 and Hiro, 1992.

27 Mizen, 2013.

${ }_{28}$ See Bunce, n.d.

29 Henry, 2006. 
The Clash) ${ }^{30}$. Desmond Dekker's 'The Israelites' is credited with being the first number one reggae record in the popular music charts in 1969, though popularity with white audiences came from a different perspective than black British audiences. The increasing influence of reggae and sound systems - rather than, for example, calypso - was part of the increasing dominance of Jamaican culture over the cultures of other West Indian islands in Britain. This development led to a virtual equivalence of the idea of Caribbean with Jamaican in white British understanding. As Stuart Hall has explained:

In the aftermath of the 1960's the word black acquired positive contemporary connotations, and profoundly transformed the possibilities for popular life. These ruptures in meaning, and the creation of new black identities, became visible day by day in alternative, cultural modes such as music, street styles and dance, where new ways of expression could be voiced, embodied and performed. Through Rastafarianism and reggae Jamaica played a disproportionate role in this global reimagining of what racial emancipation might promise. ${ }^{31}$

There was more to black musical resistance than listening to vinyl records (often on pirate radio stations, since mainstream stations played little reggae). By the 1970s, sound systems had become crucial parts of a counterculture that expressed a sense of identity and pride in blackness and the black presence in Britain.

Sound systems consisted of a turntable, an amplifier, a variety of speakers and often a microphone. As Gilroy explains, in a sound system 'records become raw material for spontaneous performances of cultural creation in which the DJ and the MC or toaster who introduces each disc or sequence of discs, emerge as principal agents in dialogic rituals of active and celebratory consumption' ${ }^{32}$. Back describes how 'echo, usually reverb, $\ldots$ adds to the atmospheric sound quality. Some sounds have installed digital delay units which have the capacity to repeat the signal from the microphone or the mixing desk. In addition, small synthesizers, or "noise boxes", enable the operator to add processed sounds" ${ }^{33}$.

30 See Stratton, 2014, p. 164-188 for the changing meanings of the song 'Police on my back' as performed by different bands since 1967 .

31 Hall, 2017, p. 100.

32 Gilroy, 1992, p. 217.

33 Back, 1988, p. 142. 
This provided layers of contribution to culture - both in the records themselves and in the overlaying lyrics of the $\mathrm{DJ}^{34}$. The combination of words and sound mattered, with amplifiers and speakers designed to boost bass sounds. Julian Henriques has noted that 'The first thing that strikes you in a Reggae sound system session is the sound itself. The sheer physical force, volume, weight and mass of it. Sonic dominance is hard, extreme and excessive. At the same time the sound is soft and embracing and it makes for an enveloping, immersive and intense experience' 35 This particular form of bass heavy sound provided a means to express black culture and identity drawing on its roots in Jamaica and its location in urban Britain.

\section{Huddersfield}

Much of the academic literature on sound systems has focused on London, where the number of people of African-Caribbean descent was highest. ${ }^{36}$ However, as Romain notes, 'St. Vincentians migrating to High Wycombe or Grenadians migrating to Kirklees, have very different narratives to tell from people migrating to London, a place which in turn has its own localised dynamics ${ }^{37}$. James Proctor has argued for a 'decentred geography' in understanding black British cultural outputs - that scholars need to look outside London to get a national perspective on culture. Terri Quaye, a black female performer, from a well-known musical family (her father came from Ghana and was a jazz singer) explained the different responses to her in different British cities: 'Safe place was Newcastle ... La Dolce Vita nightclub ... Manchester lots of different clubs was ok ... Liverpool was ok ... port towns ... white audiences ... they were fine ... horror upon horror is Leeds ... It was so racist ... Bath was a nightmare's8.

34 See Henry, 2006, for an account by a deejay and academic.

${ }^{35}$ Henriques, 2003, p. 451. YouTube has a number of recordings of sound systems, see, for example, Sir Coxsone sound system (London-1979), https://www.youtube.com/ watch?v=IZTrT2rkKXA\&t=691s and Jah Shaka sound system (late 1970's-early 1980's) https://www.youtube.com/watch?v=6guQO9Jenos

36 See Henry, 2006; Back, 1988.

37 Romain, 2006, p. 7

38 Gildart, 2013, p. 127. 


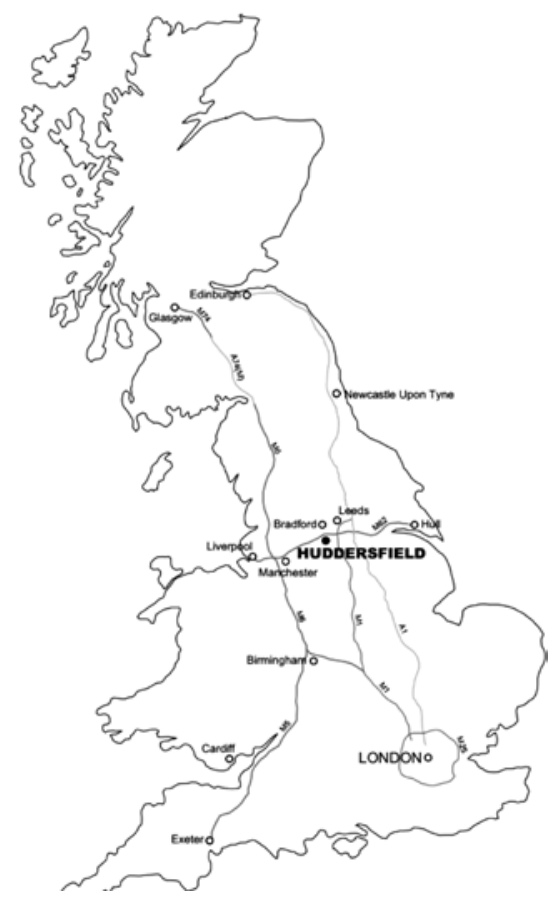

Figure 1

Huddersfield's location in the UK

The experience for people living in Huddersfield with its population of just over a hundred thousand was very different from living in the urban sprawl of London, Birmingham and Manchester (though black residence and cultural spaces were limited to particular areas in these cities). Huddersfield had experienced Commonwealth immigration from the $1950 \mathrm{~s}^{39}$ and, as with elsewhere, reaction to Asian and black immigrants was varied. A short film made in 1968 held by the Yorkshire Film Archive entitled 'Huddersfield International Club Opening Night' has the narrator and filmmaker explain that 'At a time when people are queuing up in the main street of Huddersfield to sign a paper in support of Enoch Powell, it's nice to find one place which is definitely in favour of racial harmony ... at the Springwood Adult Education

39 Ali, 2010; Kirklees Local TV, Caribbean Through the Lens. 
Centre and tonight is the first night of what we hope will become a great success as the Huddersfield International Club'40. Another archived film, made by the West Yorkshire Police in 1974 and 1975, shows demonstrations by the National Front (NF), an openly racist political organisation founded in 1967. The film also shows opposition to the fascists, mainly from the white left, though there are oral accounts of immigrants actively opposing the far right. ${ }^{41}$ The NF considered locating its headquarters in Huddersfield because of high electoral support. In 1970, they stood in 13 of the 15 wards and averaged more than ten per cent of votes cast. A concerted campaign by local activists from the radical left and trade unions reduced NF interest in the area, before their national decline in the late 1970s. Nonetheless, as Paul Gilroy has argued, anti-racism often diverted its efforts in an 'anti-Nazi' direction rather than tackling institutional discrimination, which had a greater bearing on the lives of black and Asian people living in Britain ${ }^{42}$.

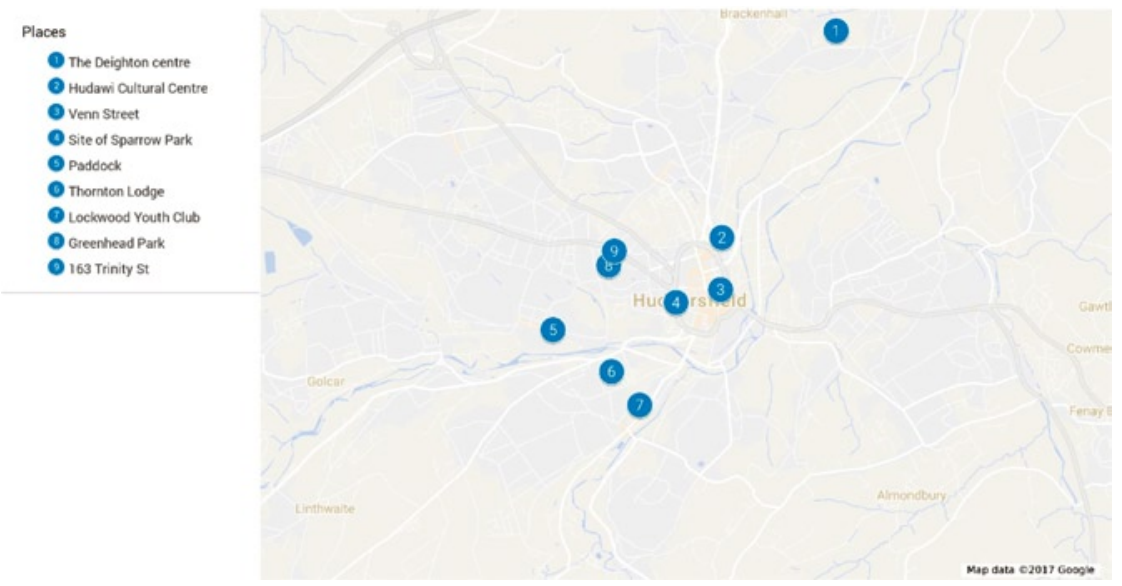

Figure 2

Significant places in Huddersfield's sound system history:

You can view this map at https://goo.gl/EjXZh8 Map data from Google with permission https://www.google.co.uk/permissions/geoguidelines.html

40 Yorkshire Film Archive, 1968. Enoch Powell was a Conservative politician who made a series of provocative racist speeches, including the 'Rivers of Blood' speech in April 1968, which suggested that violence was inevitable if immigration continued. See Hirsch, 2018.

41 Ward, Hellawell and Lloyd, 2003.

42 Gilroy, 1992. 
In Huddersfield, as elsewhere in the UK where African-Caribbean people settled, a culture of blues parties and shebeens emerged to counter exclusion from white leisure spaces - the public houses and dance halls in town centres. The Sound System Culture oral histories throw light on the location-specific racism experienced in Huddersfield, beneath the shadow of the Pennines. It is necessary to recount several memories of racism to show its extent and impact. Hermelyne Gayle (Sir Debonaire Sound System) told of the unexpected nature of the response to her as an immigrant from Jamaica in 1960: 'People were not open like us in the West Indies, there was more racism in this country than we ever thought there would be'43. Eustace Simpson, born in Jamaica, moved from London to Huddersfield in 1964 to work in the textile mills. He told interviewers that socialising was difficult when he first arrived in Huddersfield: 'It was rough, you know. We went to plenty of pub and ting but we couldn't get a drink in there. We couldn't even get a cigarette to buy in there. As you enter the door, somebody push you back out' ${ }^{\text {'4 }}$. Peter John AKA DJ Positive, whose father migrated from Jamaica to Huddersfield in 1959, said that there was 'Blatant racism in them days. He [his father] used to get beat up a lot, that was a part of life. That's why they used to walk round in groups in them days, the black people had nowhere to go' ${ }^{45}$. Fitzallan Caesar (Papa Scorpion City Sound System), whose parents came from Carriacou, Grenada, in the mid-1950s said that, 'When you had a car, you couldn't go anywhere. As soon as you're driving a car, every minute stopping, stopping, check, check, check. Is this your car? Is this your car? One night I got stopped 3 times in my car. And they want search me'46. There were varieties of racism. Claston Brooks explained that, 'When I came here in the 1960s it was a culture of skinheads and bovver boys, and that was a time of racial discrimination of black people. If you're black and you go to see a house to rent it, "sorry, there's no vacancy", and there is a vacancy but if you're black you don't get the room'47. Yvette Marks-Noel came to Britain from Jamaica when she was twelve: 'over here,' she said, 'suddenly you had to watch your back. You can't go out alone at certain

\footnotetext{
${ }^{43}$ Sound System Culture oral history interview, Aubrey and Hermelyne Gayle.

44 Sound System Culture oral history interview, Eustace Simpson.

45 Sound System Culture oral history interview, Peter Johnson AKA DJ Positive.

46 Sound System Culture oral history interview, Fitzallan Caesar, Papa Scorpion City Sound System.

47 Sound System Culture oral history interview, Claston Brooks AKA Dan Man.
} 
times at night. You had to have somebody with you because you could be attacked by men that's just being racist. If it were just verbal abuse you could cope with that, there is always words you could throw at them, But when it come to physical abuse they will just get out of a taxi, if they were driving past, and just attack you... just because you were black'48. Ras Lion said, 'I've walked down Manchester Road before and I've been shot at with an air rifle. Things like that make you aware of how people are towards you' ${ }^{49}$. Racism, in its many forms, was part of being black and living in the United Kingdom. It happened to all families; the experience was shared and had a corrosive effect on any sense of British identity, as well as impacting on material considerations like employment, education and housing.

A significant cultural response to racism and living in a hostile country was to listen to music, not passively, but actively as part of a group of likeminded people with a developing sense of a common black identity. Sound systems, which had their origins in the Jamaica, became a standard feature of areas with high African-Caribbean settlement ${ }^{50}$. Most houses had a radiogram, a combined radio and record player built into a cabinet with a speaker. Denford Thomas said that 'People would use the radiogram to have a little party in their house. This is the mid-sixties coming on to the seventies ${ }^{\prime 51}$. These grams were often the basis for building a sound system. Charles Brown said, 'I remember my brother Horace coming home from school one day with a speaker box, we'd acquire a speaker from somewhere, connect the speaker to me gram....in those days every house had a gram. Them times a man might throw out his gram coz it's broken down, and we'd take the speaker from that put it in a little box and that's how we got our little system going' ${ }^{52}$. Then the builders would become more sophisticated and allowed the crew to go public: 'The first thing we bought was one of them disco turntables, bought it from Organ Loft in town. Then we bought a valve amplifier, didn't have speakers yet. First speaker

48 Sound System Culture oral history interview, Yvette Marks-Noel.

49 Sound System Culture oral history interview, Ras Lion, Technics World Beat Sound System.

${ }^{50}$ For the origins of sound systems, see, for example, Cooper, 2004.

51 Sound System Culture oral history interview, Denford Thomas, Turbo Charge Sound System. See Riley, 2014, p. 104-105 for the genres of music played on radiograms in different households.

52 Sound System Culture oral history interview, Charles Brown, Mount Zion and King Maestro Sound System. 
we bought was a 15 -inch speaker because we didn't know no better then bought some boxes from another sound called Jah Conqueror... and then we progressed from there. We became Scorpion and we start playing at Lockwood Youth club on a regular basis, a Tuesday night was our thing ${ }^{53}$.' Similarly, Peter Johnson explains that in 1979, a few of his friends suggested building a sound system: 'With a few connections from Venn Street we ended up with some second-hand speakers, we re-coned them and started from scratch, we got an amplifier and used that. It took us until 1980/1 before we came out with a sound system, it took that long' ${ }^{54}$.

Sound systems were largely confined to black areas, as Howard Belafonte, who started as Youthman in 1978 before becoming Armagideon Sound System in 1983, explained: 'Them days, we played in the Hudawi Centre, the old Hudawi used to be called Birkby Civic Youth club, so we used to play in there, we used to play at Teapot Chapel, it's a Mosque now on Halifax Old Road, we used to play there, we used to play at Deighton Youth club, which is the Deighton Sports Arena now, and we used to play at Lockwood Youth club'55. In Huddersfield, the clubs and community centres gave black people the opportunity to find points of safety. The Sparrow Park Club in Springwood and the Arawak Club in Paddock provided cultural spaces in the neighbourhoods where they lived. But there were limits, since these were areas outside of the town centre - areas of immigration. They acted as a positive force and enabled a sense of community to develop (alongside other community organisations such as the Antilles Club in Trinity Street ${ }^{56}$ ). Aubrey Gayle locates the importance of sound systems in the class experience of West Indians in Huddersfield. Most had come to work in textiles, in engineering and in transport in blue collar jobs. He thought that 'Sound systems in Huddersfield was a good thing for the community because it gives us something to look forward to at the weekend after hard graft during the week, working or looking after children, it's a nice release, somewhere to go and let your hair down' 57 . Furthermore, sound systems enabled claiming ownership of space, so Orville 'Bigga Puss' Pusey said that, 'We used to have a lot of street parties...

53 Sound System Culture oral history interview, Fitzallan Caesar, Papa Scorpion City Sound System.

${ }^{54}$ Sound System Culture oral history interview, Peter Johnson AKA DJ Positive.

55 Sound System Culture oral history interview, Howard Belafonte.

56 Huddersfield Examiner, 2010.

57 Sound System Culture oral history interview, Aubrey and Hermelyne Gayle. 
we'd just string up the sound, get a couple of drinks, put out invitations, and people used to come. Police might come round and say turn it down a bit but they were alright with it ${ }^{58}$. But there were limits to this ability to express Caribbean culture in Huddersfield. Ras Lion, Technics World Beat Sound System, said that: 'Where I actually lived, down in Thornton Lodge Spring Dale side, we all grew up together - Black, White, Asianwe were all cool. There was no problem. But, as we hit town, bam, that's when things just went different. So, we just had to be really on us guard when we went to town, other than that we were alright' 59 .

Potentially, then, West Indian culture was to be contained in the periphery of the town, in its areas of immigrant settlement and ethnic diversity. This is where Venn Street came to be of central importance. Venn Street was a leisure venue in the town centre, in the traditional nightlife centre for the young workers in the mills, factories and mines in and around Huddersfield ${ }^{60}$. One of the larger venues, known as the Empress Ballroom until 1963 and then the New Theatre until 1967, was owned by a Sikh called Sohan Singh Bhullar and he was prepared to do business with the West Indian community.

In 1967 the West Indian Social Club was founded in this building in Venn Street. Fitzallan Caesar explains how it fitted into black lives in the town, enabling music to take on even more importance in facing up to racism and hostility: 'But the black race for us growing up in the 1970s and early 1980s was hard with the police and the sus law,' he said. 'Music helped. And that's another thing, coz we had a place to go, we had Venn Street. If you didn't go to Venn Street you'd go to Arawak, if you didn't go to Arawak you pass down Morillo. And you had the blues. You had to go to the blues. There was nothing like the blues' ${ }^{\prime 1}$. This network of social and musical locations ran off the hub of Venn Street. Its town centre location was symbolically important. Derrick Johnson, whose cousin had run the Arawak club, took over the West Indian club in the early 1970s. Derrick had migrated from St Elizabeth, Jamaica, in 1959: 'I used to go

58 Sound System Culture oral history interview, Orville 'Bigga Puss' Pusey, Shakatine and King Broadway Sound System.

59 Sound System Culture oral history interview, Ras Lion, Technics World Beat Sound System.

${ }^{60}$ For an account of Venn Street in the early 1960s, see Jackson, 1968.

61 Sound System Culture oral history interview, Fitzallan Caesar, Papa Scorpion City Sound System. 
out with some friends to the pub, or to blues dance... used to go to Sparrow Park club, and then when my cousin opened his club in Paddock, The Arawak club, we used to go there.' His cousin had set up the Arawak to give black people a place to go and this encouraged Derrick to think about the Venn Street venue. The connection of the venue to the Black Atlantic was evident in its name. 'It was [called] Cleopatra [in the 1970s], and I changed the name to Silver Sands because of some friends I had living in Jamaica, they had a hotel by the name of Silver Sands in Negril. I decide to call the club Silver Sands' ${ }^{\prime 2}$.

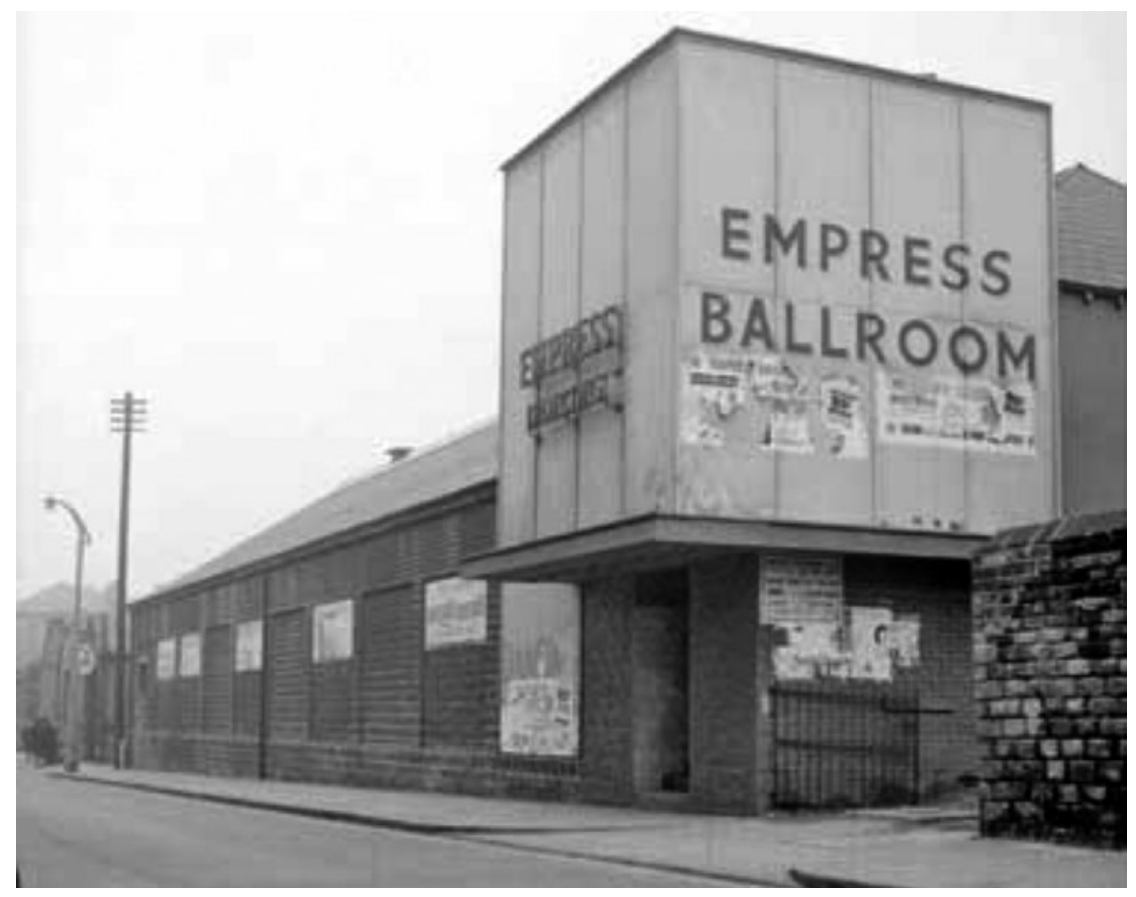

Figure 3

The Empress Ballroom, Venn Street, Huddersfield.

The home to a series of West Indian clubs in the town centre.

Image courtesy of Kirklees Image Archive/Daily Examiner (Trinity Mirror)

${ }^{62}$ Sound System Culture oral history interview, Derrick Johnson. 
Venn Street provided a place in the town centre available in the heart of Huddersfield's nightlife. It made it normal for black people to be in the town centre. Even by 1971, it was sufficiently important for the (white) reggae band The Inner Mind to record a B side called 'Venn Street Rub' $^{\text {' } 3}$. It provided a venue for local sound systems to engage in sound clashes with systems from other towns and cities in the $\mathrm{UK}^{64}$. Its resident sound system was King Iman Rockers, which had various sections of speaker boxes with six 18-inch bass drivers per box, with Matamp amplifiers, made locally. ${ }^{65}$ Peter Johnson said, 'You had to be big to challenge the resident sound in Venn Street, it was daunting for any sound system to go in there' 66 .

Some of the very biggest sound systems came to Huddersfield to play at Venn Street. In 1981 or 1982 Coxsone Sound played: 'It was full from one end to another, that was a dance I've never forgot... Coxsone was the biggest sound in England back then... they introduced a lot of new artists that night and I said to myself, "boy, yes, this is a dance" and it was so packed you could hardly move but there was no trouble, everybody enjoying themselves, it was talked about for months' ${ }^{67}$. As its reputation grew, the venue started to attract big names in reggae, so Bigga Puss explains that 'Venn Street was on the map, every artist that came from Jamaica performed in Venn Street, I've seen them all; Burning Spear, Culture, John Holt, Gregory Isaacs, you name it... even sound systems from Jamaica too, Jah Love, Gemini, Ray Symbolic, a lot of sounds' ${ }^{68}$. This drew people from around the UK, making Huddersfield a centre of reggae culture disproportionate to its size. Through Venn Street, and through other community activities, such as the opening of the Hudawi Centre (Huddersfield Afro-West Indian Centre), just on the edge of the town centre, and the establishment of the African-Caribbean Carnival in the $1980 \mathrm{~s}^{69}$, the African-Caribbean community in Huddersfield developed a sense of genuinely civic identity and importantly a sense of ownership of

\footnotetext{
${ }^{63}$ https://www.youtube.com/watch?v=iKYdMcXzwhw Venn Street Rub, Ian Smith and the Inner Mind, 1971.

${ }^{64}$ For an audio recording of a clash in Venn Street, see Earth Rocker v Yabbys Tafari @ Venn St Huddersfield 1983. https://www.youtube.com/watch?v=pPQEeaUA0nc

65 Samra and Fingers, p. 79; For Hans Alfred 'Mat' Matthias, see p. 68-70.

66 Sound System Culture oral history interview, Peter Johnson.

67 Sound System Culture oral history interview, Bigga Puss.

68 Sound System Culture oral history interview, Bigga Puss.

${ }^{69}$ Connor and Farrar, 2003.
} 
the town centre and a pride in their contribution to the town's culture. Andrew Johnson AKA Diamond Finger, suggests that,

Everybody was friendly to each other because they knew each other or because they were new immigrants and they felt they had to stick together. Venn Street was unique in that it was the first in the north that had significant acts, so the Sheffield people, Manchester people, Rochdale, Bradford, Leeds, wherever, they would come. There was a lot of talking, they'd be playing dominoes, exchanging stories about life, it was very harmonious, very friendly ${ }^{70}$.

In retrospect, a sense of nostalgia is invoked by the success of Venn Street, though its symbolic power was in reggae and sound systems' militancy. Mark Iration, from Leeds-based Iration Steppas Sound System, which played Huddersfield regularly, recalls that 'Back in the days it was a black thing. Back in the days it was militant, it was a black thing strictly... you went there and it was black people together having a nice time. The vibes was different. It was more like we went there for music, and to go skank. Not dance, skank. Everywhere we went we used to go there and skank. Skanking was militant style African dancing but with moves" ${ }^{71}$. Rastafarianism had some impact in Huddersfield ${ }^{72}$. Claston Brooks said: 'The sound system, the music, made me become Rasta, because when I'm listening to the music the words are spiritual, it makes me become spiritual. By listening to the music, it teaches you to do good things, don't do bad things, don't do evil works... that's what helped me become a Rasta, also by reading the bible as well'73. Howard Belafonte said that 'The Rasta and the sounds kept us focused'74. Natalie and Arden Pinnock-Hamilton consider that Rastafarianism 'was important because it was telling a story. It was about history, it was about the struggles, it was about the way forward, it wasn't just music for the sake of music. The roots music was telling people about their history that wasn't taught in school... so young people gravitate towards that sort of music ${ }^{75}$.

70 Sound System Culture oral history interview, Andrew Johnson, AKA Diamond Finger, King Maestro Sound System.

71 Sound System Culture oral history interview, Mark Iration, Iration Steppas Sound System

${ }^{72}$ For a contemporary academic account of Rastafarianism, see Cashmore, 2013.

73 Sound System Culture oral history interview, Claston Brooks

${ }^{74}$ Sound System Culture oral history interview, Howard Belafonte

75 Sound System Culture oral history interview, Natalie and Arden Pinnock-Hamilton 
Many West Indians were hostile to Rastafarianism, but its opposition to white racism was part of a spectrum of stances that emerged from the development of sound system and reggae culture located in the centre of Huddersfield. Sound systems were adorned with the symbols and red, gold and green of global Rastafarianism, but were located in particular places.

Similar cultural developments were played out in other areas of West Indian settlement in Britain, but the configuration in each place differed according to size and patterns of residence. The Sound System Culture project that originated in Huddersfield travelled and undertook similar projects in Birmingham, Bristol and south London, capturing and archiving comparable personal stories played out against the bass heavy sounds of reggae and with commentaries provided by deejays across England. Hewan Clarke says about living in Moss Side, Manchester, that 'there were two clubs where if you were black you were guaranteed getting in with no problem whatsoever. Any of the other clubs in Manchester you could turn up at and you could probably get stopped by the doormen or something like that - you weren't always sure that you were going to get in'76. Studies, often community-based, of Bristol and Northampton have similarly revealed the importance of sound system and reggae venues ${ }^{77}$.

\section{Heritage}

In the early twenty-first century, austerity in Britain has gone a long way towards stripping out the cultural centres of communities, resulting in a sense of loss and trauma. The future seems uncertain and there are anxieties about the loss of community that combine with concerns that young people will forget black history and their part in it. Eddie Chambers, a black art historian, has commented that, 'Now, in 2017, though very few of the problems faced by black people in Britain have gone away, ... what has dissipated is the once distinct black Britain. The connection, resistance and rhetoric slowly faded. Immigration continued from various other continents and the next generation of black children perhaps found it easier to assimilate'78. In Huddersfield, this is compounded by the uncertainty over the future of its carnival founded in 1984. It failed to take place in 2016 for the

\footnotetext{
76 De Mello, 2012. See also Moss Side Stories, n.d.

77 Hyder, 2014; Gardner, 2016; Watley, 2011.

78 Chambers, 2017.
} 
first time in thirty years and struggled to raise money needed for July 2017, though it went ahead by starting and finishing at the Hudawi Centre rather than at Greenhead Park, where most major cultural events take place in the town. There is, therefore, a desire to capture a history of African-Caribbean culture, that in Huddersfield has come to focus, in part, on sound system culture. There is a clear and continuing celebration of the origins of sound systems and reggae in the Caribbean - the Black Atlantic is invoked in a variety of ways, but there is also an emphasis on the locality - on Huddersfield's contribution to sound system culture and black history more generally. This has come to represent the town's history more broadly, with aspects of the town's tourism promotion emphasising the development of multi-ethnic culture in Huddersfield ${ }^{79}$, but with most of those involved in preserving Huddersfield's cultural heritage focusing on its implications for identity in the past and the future rather than its economic possibilities ${ }^{80}$.

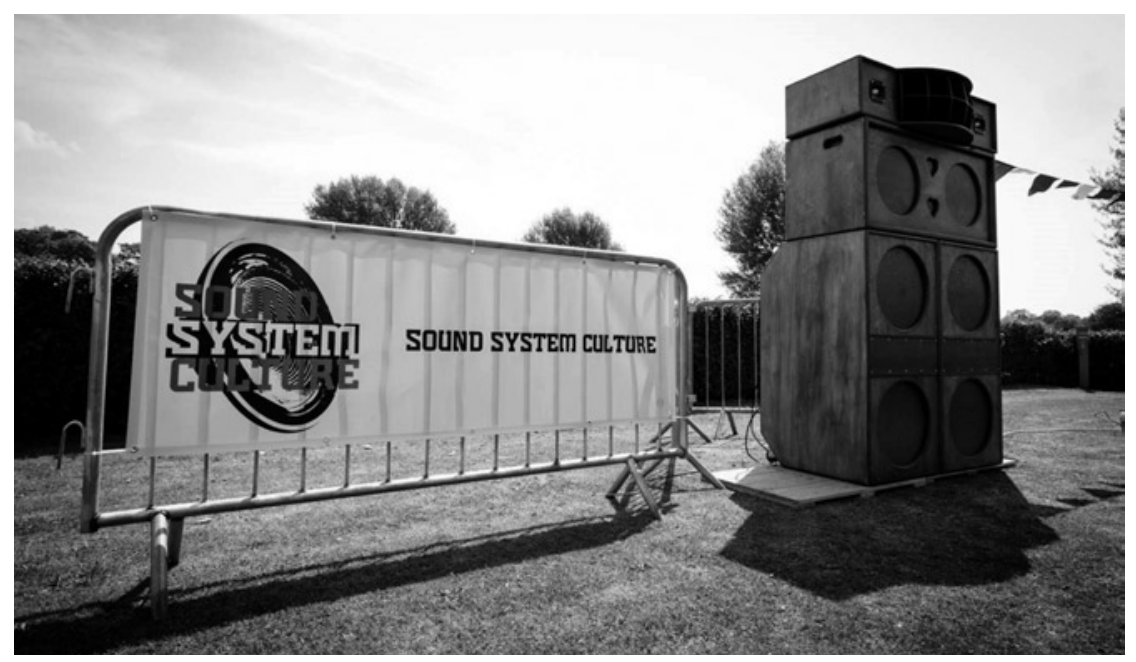

Figure 4

Sound System Culture's Heritage HiFi speaker stack, build by Paul Huxtable. Photo by Elliot Baxter. Image courtesy of Let's Go Yorkshire.

79 See for example the guided walks run by Discover Huddersfield, that include walks on music and Caribbean heritage in the town. http://www.discoverhuddersfield.com/trails/

${ }^{80}$ See for example Kirklees Local TV's films on black history. http://kirkleeslocaltv. com/video/ 


\section{Conclusion}

Paul Gilroy examined how, in the 1970s and the 1980s, people of colour in Britain began to fashion for themselves a black British identity, even in the face of racist conceptions of the British nation and national belonging as essentially white ${ }^{81}$. This should encourage thinking about the contribution that local history makes to black history and to understandings of the Black Atlantic. Most (white/British) local histories are determinedly local, yet histories of sound systems and other cultural forms are inextricably global even when they focus on a bounded locality. William Gould and Irna Qureshi have explored south Asian histories in Britain in the context of the postcolonial migrant experience, arguing that local histories need to take account of the imperial nature of British history ${ }^{82}$. At the same time, black histories need to take account of how people view the world from their house, neighbourhood, district and town/city. Caroline Bressey uses the phrase 'geographies of belonging' to uncover the lives of black women in Victorian Britain and it is a concept that can be applied to think about the geographical shape of people's lives in localities, in a variety of historical circumstances. In sound systems, geography mattered. It mattered whether soundmen (and they were usually men) and their audiences lived and played in Huddersfield rather than London or Birmingham. This faces black British history with a significant task to uncover and collect, record and analyse and interpret the black historical experience sufficiently that it becomes part of the 'mainstream' British historiography used in universities, particularly in light of the apparent inability of academia to overcome engrained institutional racism in British universities, in which there are very few black lecturers and professors ${ }^{83}$. Bressey suggests that, 'Cultivating more interactive partnerships with community scholars and research groups may be one way for academic historians of Britain and in Britain to enliven our research and deepen our connections with our local communities' ${ }^{84}$. Black history in Britain has always been a public and community-based history and has been about identity in the present and future as well as in the past.

\footnotetext{
81 Gilroy, 2002.

82 Gould and Qureshi, 2014.

83 Adams, 2017.

84 Bressey, 2013, p. 554.
} 
There are a series of developments that seek to encourage the study of black British history, including the Black and Asian Studies Associations, whose strapline is the African proverb 'Until the lion has its own historian, tales of hunting will always be of the hunter ${ }^{85}$.' BASA is an organisation of university and community-based members with a lively email discussion list. In universities, there are a number of initiatives, such as the Arts and Humanities Council-funded Reggae Research Network $^{86}$ and the Bass Culture project that explores the culture, history and legacy of Jamaican music in Britain ${ }^{87}$ and these also cross the boundary into community-based research. The challenge is to think about how to ensure that the historiography of modern Britain includes and integrates histories of the black presence. As early as 1981 Ian Duffield asserted that historians should explore the history of Black Britons 'as a facet of Black and Asian diaspora history' but also as 'part of the general British historical inheritance' ${ }^{88}$ More recently, Priyamvada Gopal has argued that "history ... must go beyond the notional largesse of "including" ethnic and cultural minorities in the national. The postcolonial must exist in a constitutive relationship to the national, not one of supplementarity' ${ }^{\prime 2}$. This applies at local and regional level as well as when exploring history and identities in Britain as a whole. An understanding of sound systems fits readily with other aspects of Huddersfield's musical heritage and the involvement of people from the West Indian and other minority ethnic communities in telling the histories of the town is crucial to understanding how its imperial and colonial past is embedded in its industrial heritage.

Les Black is surely right to argue that 'it would be wrong to overstate the social or political effectiveness of the sound systems" "didactic populism". They have no real impact on the conditions which perpetuate inequality; their role is better viewed as that of a primer'90. In Huddersfield, they did enable black encroachment into the town centre to place West Indian culture at the heart of the town, and through the

85 BASA, n.d.

86 Reggae Research Network, n.d.

87 Bass Culture, n.d.

${ }^{88}$ Ian Duffield, 'Blacks in Britain: History and the Historians', History Today, 31 (1981), pp. 34-36.

89 Gopal, 2016, p.

90 Back, p. 151. 
agency of heritage projects on sound system culture and black history to assert 'the historical dimensions of black life in this country' 91 and in Huddersfield.

\section{Sources}

Kirklees Local TV, «Caribbean Through the Lens», https://www.youtube.com/ watch? $\mathrm{v}=$ puG7bpEFpJ0

Kirklees Local TV, «Venn Street Reunion Pt. 1», https://www.youtube.com/ watch?v=JfH5Swi6iis

Kirklees Local TV, «Venn Street Reunion Pt. 2», https://www.youtube.com/ watch? $v=$ GiMcQD9R1-c

Kirklees Local TV, «Huddersfield Sound System Culture Project Launch», https://www. youtube.com/watch?v=6gfG1Z190qs\&t=19s

Let's Go Yorkshire, https://www.facebook.com/letsgoyorkshire/

Sound System Culture oral history interviews.

Sound System Culture, http://soundsystemcultureblog.tumblr.com/

Yorkshire Film Archive, http://www.yorkshirefilmarchive.com/film/huddersfieldinternational-club-opening-night, 1968.

\section{Bibliography}

ADAMs, Richard, «British universities employ no black academics in top roles, figures show» https://www.theguardian.com/education/2017/jan/19/britishuniversities-employ-no-black-academics-in-top-roles-figures-show January 2017.

AlI, Nafhesa, Asian Voices: First generation Migrants, University of Huddersfield, Huddersfield, 2010.

BACK, Les, «Coughing up fire: Sound systems in south-East London», new formations, . $^{\circ} 5,1988$, p. 141-152.

BAKARI, Imruh, «Calypso and reggae», SAMUEL, Raphael (ed.), Patriotism: National Fictions: The Making and Unmaking of British National Identity: National Fictions Volume 3, Routledge, London, 1989, p. 99-122

BASA (Black and Asian Studies Association) http://www.blackandasianstudies. org/

BASS CUlTURE, http://www.basscultureresearch.com/

91 Gilroy, 1992, p. 18. 
Bradley, Lloyd, Bass Culture: When Reggae Was King, Penguin, London, 2001. BRESSEY, Caroline, «Geographies of Belonging: white women and black history», Women's History Review, vol. 2, n. ${ }^{\circ} 4$, p. 541-558.

Bunce, Robin, «Darcus Howe and Britain's Black Power movement» http:// www .ourmigrationstory .org.uk/oms/darcus-howe-and-britains-black-powermovement, n.d.

CASHMore, Ellis, Rastaman: The Rastafarian Movement in England, first published 1979, Routledge, London 2013.

CHAmbers, Eddie, «What happened to black British solidarity?» http://www. dazeddigital.com/artsandculture/article/35537/1/what-happened-to-blackbritish-solidarity, 2017.

Cooper, Carolyn, Sound Clash: Jamaican Dancehall Culture at Large, Palgrave Macmillan, Basingstoke, 2004.

CONNOR, Geraldine and FARRAR, Max, «Carnival in Leeds and London, UK: Making New Black British Subjectivities», RIGGIO, Milla Cozart, Culture in Action, Routledge, London, 2003, p. 255-269.

De Mello, Martin (ed.), Moss Side Stories, Crocus, Manchester, 2012.

GARDNER, Noel, «Why Bristol is Culture Clash's spiritual home» https://www. redbull.com/gb-en/bristol-sound-systems-a-history, 2016.

GILDART, Keith, Images of England through Popular Music: Class, Youth and Rock 'n' Roll, 1955-1976, Palgrave Macmillan, Basingstoke, 2013.

Gilroy, Paul, There Ain't No Black in the Union Jack: The Cultural Politics of Race and Nation, Routledge, London, 1992.

GoPAL, Priyamvada, «Redressing anti-imperial amnesia», Race and Class, vol. 57 n. 3,2016 , p. 18-30

GOULD, William and QURESHI, Irna, «South Asian histories in Britain: Nation, locality and marginality», McLoughlin, S., Gould, W., KABIR, A.J., Tomalin, E., Writing the City in British Asian Diasporas, Routledge, London, 2014, p. 137-157.

Hall, Stuart; Critcher, Charles; JefFerson, Tony, Policing the Crisis: Mugging, the State and Law and Order, Palgrave, Basingstoke, 2013.

Hall, Stuart, Familiar Stranger: A Life between Two Islands. London, Allen Lane, 2017.

Hebdige, Richard, «Reggae, rastas and rudies», Hall, Stuart and JefFerson, Tony, Resistance through Rituals: Youth Subcultures in Post-war Britain, second edition, Routledge, London, 2006, p. 113-128.

Henriques, Julian, «Sonic Dominance and the Reggae Sound System Session» Bull, M.; BACK, Les, The Auditory Culture Reader, Berg, Oxford, 2003, pp. 451-480.

Henriques, Julian, Sonic Bodies: Reggae Sound Systems, Performing Techniques and Ways of Knowing, Continuum, London, 2011.

Henry, William [Lez], What the Deejay Said: A Critique from the Street, Nu-Beyond, London, 2006. 
HIRo, Dilip, Black British, White British, second edition, Paladin, London, 1992.

HIRSCH, Shirin, In the Shadow of Powell: Race, Locality and Resistance, Manchester University Press, Manchester, 2018.

HuDDERSFIELD EXAMINER, «How the founders of Huddersfield's Caribbean community thrived», http://www.examiner.co.uk/news/west-yorkshire-news/ how-founders-huddersfields-caribbean-community-4985444, 2010.

HydER, Rehan, «Black music and cultural exchange in Bristol», STRATTON, Jon; ZuBERI, Nabeel, Black Popular Music in Britain since 1945, Ashgate, Farnham, 2014, p. 85-99.

JACKSON, Brian «Riot», in his Working-Class Community: Some General Notions raised by a Series of Studies in Northern England, Penguin, Harmondsworth, 1968.

KATZ, David, Solid Foundation: An Oral History of Reggae, Bloomsbury, London, 2003.

MEAD, Matthew, «Empire Windrush: The cultural memory of an imaginary arrival», Journal of Postcolonial Writing, vol. 45, n. ${ }^{\circ}$ 2, 2009, p. 137-149.

Mizen, Spencer, «The great British civil rights scandal: The Bristol bus boycott», http://www.historyextra.com/article/premium/great-british-civil-rightsscandal-bristol-bus-boycott, 2013.

MOSS SIDE STORIES, https://www.mdmarchive.co.uk/exhibition/id/76/MOSS SIDE_STORIES.html, 2012.

Panayi, Panikos, Racial Violence in Britain in the Nineteenth and Twentieth Centuries, Leicester University Press, Leicester, 1996.

Pilkington, Edward, Beyond the Mother Country: West Indians and the Notting Hill White Riots, I.B. Tauris, London, 1988.

RAMDIN, Ron, Making of the Black Working Class in Britain, Ashgate, Farnham, 1987.

REGGAE RESEARCH NETwORK, https://reggaenetwork.wordpress.com/

RILEY, Mykaell, «Bass culture: An alternative soundtrack to Britishness», STRATTON, Jon; Zuberi, Nabeel, Black Popular Music in Britain since 1945 , Ashgate, Farnham, 2014, p. 101-114.

RomaIn, Gemma, Connecting Histories: A Comparative Exploration of AfricanCaribbean and Jewish History and Memory in Modern Britain, Kegan Paul, London, 2006.

RusH, Anne, «Reshaping British history: The historiography of West Indians in Britain in the Twentieth century», History Compass, vol. 5, n. ${ }^{\circ}$ 2, 2007, p. 463-484.

Rose, E.J.B., Colour and Citizenship: A Report on British Race Relations, Oxford University press, Oxford, 1969.

SAmra, Mandeep; FIngers, Al, Sound System Culture: Celebrating Huddersfield's Sound Systems, One Love, London, 2014.

SEARLE, Kevin, «Mixing of the unmixables': The 1949 Causeway Green 'riots' in Birmingham», Race and Class, vol. 54, n. . 3, 2013, p. 44-64. 
SivanAndan, A., «From Resistance to Rebellion Asian and Afro-Caribbean Struggles in Britain», Race and Class, vol. 23, n. ${ }^{\circ} 2-3,1981$, p. 111-152.

SOUND SYSTEM CULTURE: HUDDERSFIELD TRAILER, https://vimeo.com/87017029

Stratton, Jon, When Music Migrates: Crossing British and European Racial Faultlines, 1945-2010, Ashgate, Farnham, 2014.

TAYLOR, David, «The Middlesbrough Race Riot of 1961: A Comment», Social History, vol. 18, n. ${ }^{\circ}$ 1, 1993, p. 73-79.

WADE, Donald, Yorkshire Survey: A Report on Community Relations in Yorkshire, Yorkshire Committee for Community Relations, Leeds, 1972.

WARD, Paul, with HELLAWELL, Graham, and LLOYD, Sally, «Witness Seminar: Anti-Fascism in 1970s Huddersfield», Contemporary British History, Vol. 20, n. ${ }^{\circ} 1,2006$, p. 119-133.

WATERS, Chris, «"Dark Strangers” in our midst: Discourses of race and nation in Britain, 1947-1963», Journal of British Studies, vol. 36, n. ${ }^{\circ}$ 2, 1997, p. 207-238.

WATLEY, George, «The cultural currency of Afro-Caribbeans in Northamptonshire c. 1960-1990», Midland History, vol. 36, n. ${ }^{\circ}$ 2, 2011, p. 245-261.

\section{Acknowledgements and Funding}

This essay could not have been written without the Sound System Culture project led by Mandeep Samra, who brought everything together to such good effect. I would like to thank the peer reviewers of the essay and Ben Kyneswood. I'm also grateful to Donald Cumming, Milton Brown, Liz Pente and Shabina Aslam and all those involved with Imagine: Connecting Communities Through Research (Economic and Social Research Council grant numbers ES/K002686/1 and ES/K002686/2).

\section{About the Author}

Paul Ward (paul.ward@edgehill.ac.uk) has just been appointed professor of Public History and Community Heritage at Edge Hill University, after eighteen years at the University of Huddersfield. His research focuses on national identities in the United Kingdom and he uses community-based research to explore how Britons have identified themselves. He is author of four books including Britishness since 1870 (2004). His recent publications include 'Let's change History! Community histories and the co-production of historical knowledge,' in Katie Pickles et al. (eds), History Making a Difference: New Approaches from Aotearoa (2017). He is currently co-editing a book called Co-Producing Research: A Community Development Approach (Policy Press), as part of the Imagine: Connecting Communities Through Research project funded by the ESRC. 